\title{
Achebe and the Linguistic Political Criticism in the Post-colonial Vision*
}

\author{
Pengju Qin \\ College of Literature and Media \\ Yulin Normal University \\ Yulin, China 537000 \\ College of Literature and Journalism \\ Sichuan University \\ Chengdu, China 610065
}

\begin{abstract}
Languages have evolved with the development of the times and with a clear ideological character. Colonial discourse is a kind of "cognitive violence". Achebe's choice of English and African native language is not a kind of racial literature that is "either this or that", but is a "nationality literature that "can be both". This linguistic and literary view presents the history and reality of post-colonial society in Africa. The language hybrid of Achebe opened up the "third space" of colonial language and African native language, and realized cross-cultural "translation" between different languages.
\end{abstract}

Keywords-Achebe; "cognitive violence"; cross-cultural "translation"

\section{INTRODUCTION}

Language changes with the development of the times and has a clear ideological character. One of the tasks of postcolonial resistance is to identify the colonial-centrism contained in language, and colonial discourse is a kind of "cognitive violence". The hybrid of different languages not only makes the source language gain vitality, but also helps to improve the expression of the target language. This is reflected in the hybrid between English and African language, Achebe ${ }^{1}$ was a typical figure in the practice of language hybrid. At the contradiction of colonial discourse, the "third space" of hybrid discourse was opened. The success of hybrid depends on the power and status of both sides of the hybrid language. The hybrid of languages is also a cultural hybrid and confrontation. Cross-cultural "translation" is formed in the hybrid of language and becomes a powerful weapon against colonial language.

\section{LANGUAGE AND IDEOLOGY}

Language is not a rigid nature, but changes with the

*[Fund Project] This is the phased achievement of 2016 Guangxi Junior High School Teachers' Basic Capability Enhancement Project "Chinua Achebe and African Traditions" (KY2016LX261) and the 2015 High-level Talent Project of Yulin Normal University "Chinua Achebe under the view of literary and political criticism" (G20150007).

Chinua Achebe, a famous African novelist, was known as "The father of modern African novels". He and Soinka were known as Nigeria's "Two Talents". development of the times. Language has a distinct ideology, and post-colonial discourse reflects a kind of "cognitive violence".

\section{A. The Evolution and Ideology of Language}

The turn of the linguistics initiated by Saussure in the 20th century shifted the passiveness of language to the active state, revealing that language is also a free system with unique operating rules. He led people to break through the notion that language is merely a tool, and instead it studies language form ontology. Saussure's merits are two: distinguish the difference between language and speech; study language from the synchronic level, the symbolic meaning of language is artificially constructed. Saussure's linguistics turns traditional diachronic research into the study of synchronicity of language. Language is not a debut in chronological order, but a combination of current meanings integrating various factors. The synchronic language concept laid the theoretical foundation for the formation of Russian formalism and French structuralism.

However, neither the formal defamiliarization theory nor the "structure" of structuralism has profoundly revealed the social historical and cultural background of language. What did people become when language changed from traditional instrumental theory to subject theory? This is exactly what the American critic Jameson is worried about: "When we speak, we think we are controlling the language, but in fact, we are controlled by language. It's not that 'I'm talking something but is something is talking about me'. The subject of talking is other not me". [1] ${ }^{29}$ This anxiety is aroused, and even Heidegger has proposed the theory of "language is the master of man", "language first and ultimately calls us to the essence of something", although Heidegger was from the real survival ontology of language to human, but the meaning of its language center is fully exposed. Language is another sight for Derrida, who lifts up the great deconstruction. He relentlessly criticized the logocentrism represented by phonetic writing in the West. It is in the atmosphere of the post-modern deconstruction trend represented by Derrida that the textual meaning constructed by language is permanently hollowed out 
and dispelled. The post-modern play spirit, "Whatever you want" becomes the most powerful symbol for text explanatory.

Whether the traditional view of language regards language as the logical decoding of meaning, or the modern view of language regards it as a self-contained structure, or postmodern masters use language as a experimental article to deconstruct the grand narrative model, all these show that language is created by people, and changes with the change of people's ideas and the times and society. It is not only a tool for mankind to perceive the world and understand the world, but also a basic form of human emotion structure, because the world that language can imagine is the world that human lives, and there is no world beyond language. This not only shows the limitations of language, but also reveals the limitations of human understanding.

Marx used a dialectical attitude in the use of language. He believed that the existence of language and the creation of language are to serve people's social interaction. Language is not only an object, but also a human communication tool. Language is created by human and makes sense only in social interactions. Marx's view of language embodies a practical view. Man is the creator of language, but man's creation of language does not make language an independent existence and becomes what Jameson said that "language speak for people". It is tantamount to language enslavement and violence against people. But in fact, there is indeed a question of violent use of language. For example, the existence of colonial discourse conveys colonialist aggression intentions through language packaging to the colonized people. Language becomes a tool for false cognition, ethnic centralism is concealed under the hypocrisy of language. It embodies a bloodless violent character of language.

The turn of linguistics in the twentieth century made people question literature: "Literature can be used as a representation (simulation, reproduction) of the world or some philosophical ideas, it can also be a distortion of the world or philosophical ideas. Literary as a mirror reflects the things it faces unfaithfully. It is entirely possible that it is a distorting mirror itself". $[2]^{61}$ This has led to the "representational crisis" of language. The postmodern masters treated the textual world constructed by language as a language game and questioned all Western rational civilizations built up by language. Foucault was such a radical skeptic that he carefully cleaned up the building process of knowledge and found that all knowledge had the power to participate. What he refers to as "knowledge" is not the knowledge narrowly defined by specialized disciplines, but refers to human understanding and cognition of the world. Foucault's interest is the cognitive process, not in the actual knowledge itself. Foucault called his knowledge as "knowledge archaeology" or "knowledge genealogy". In the archaeology of "knowledge", Foucault discovered that "knowledge" is "a combination of certain forces. It is the nature of certain specific benefits". The work Foucault did was to examine how the "knowledge" is formed, how the "knowledge" and the various powers are intertwined, and how the words that reflect the "knowledge" are produced. By examining past knowledge, Foucault discovered that all human knowledge has a conspiracy relationship with power. "The true discourse is floating on the surface in a form that is distorted by violence".[3] $]^{63}$

In the post-colonial era, people want to acquire a subsistence right, first of all, it is a subsistence right of language. Use the rhetorical nature of the native language to counter the logic of the Western language, use the "translation" of language and culture to break the hegemonic power and homogenous space dominated by the imperial language, "so as to obtain an independent, autonomous, and his own language space". [4] ${ }^{201}$

\section{B. Colonial Discourse and "Cognitive Violence"}

Fanon pointed out that: "Speaking a language is consciously accepting a world, a culture". [5] 25 People cannot think outside the language, language communication its essence is the exchange of thoughts. Then, how do we achieve a profound understanding of the thoughts during the communication of language? For example, colonists used colonial language in Africa (take English as an example), how could the colonized people discriminate colonial thought contained in the language of their own works written in English? For an intuitive, naked colonial language, colonized people are easier to aware. But how can they aware the colonial thought hidden under the language? Because "language in any case not only conveys something that can be conveyed, but it is also a symbol of something that cannot be conveyed".[6] ${ }^{290}$ Therefore, in addition to seeing the meaning of the language surface, the colonized people should explore more about the underlying significance of the language.

Sartre believes that the use of language is historic. The combination of words leaves us with only a few superficial meanings, but more meanings are beyond words. [7] The meaning within language is a literal manifestation, but the meaning outside language is closely related to the historical practice of human beings. It requires us to go through the surface of language and enter into the language for deep thinking. To some extent, discovering the unconscious under the colonial discourse is a work that is more worthwhile for the colonized people. It is the nature and real desire of the colonists. They are hidden in the language and rely on language modification and discourse cover-up and disguised as a form of "goodness", overlooking the colony with the "savior" and humanitarian concerns, but the colonized people were ignorant. The truly keen colonial intellectuals are to expose the lies under this language, to expose the hypocritical nature of the colonists and the silent colonial thought that they throw to the colony through the cover of language.

The post-colonial theorist Spivak believes that colonial discourse this set of tricks can be described as the "cognitive violence" of language. It refers to cultural exclusion and cultural reshaping behaviors that colonial imperialism conduct to colonial place in the form of rational scientific knowledge, universal truth, and religious salvation. "Cognitive Violence" adopts a cultural strategy to silence the colonial people, thus attaching the colonized subject to the colonial subject; at the same time, it is cloaked with civilization and provides the basis for legalization of the fact of colonial invasion. In A Critique of Postcolonial Reason, Spivak carefully analyzed Kant's 
enlightenment philosophy. In her view, Kant's cultural concept divides people into "civilized people" and "rough people". "Rough people" must accept the cultural correction of "civilized people", but this is an unfinished work. "Although the cultural tasks of imperialism will never be successfully completed, it must still be done".[8] ${ }^{15}$ This is a cultural correction task based on Kant's analysis of "sublimity". Kant believes that sublimity is not based on culture, but on human production. Culturally savvy people should naturally accept cultural corrections because they do not have a sense of cultural sublimity. Not only that, Kant also extends the purpose of man from good to God. From the desire to the morality, from morality to religion, people perfect themselves, develop them, and achieve the goal of human beings, all these will be implemented through the will of goodness. This "self-evidence axiom" was born at the expense of the rejection of other civilizations. The most crucial point was that this moral order made westerners a sense of mission and responsibility to domesticate non-Westerners, only after change who they believe was "barbarians" into human, so that it can be seen as its own purpose. It can be seen that the cultural superiority and noble moral sense of Westerners is inseparable from Kant's contribution.

The colonial discourse is even more magnificent. The colonists of all kinds have joined the colonial invaders with the banner civilization and the gesture of the savior, in order to make a reasonable knowledge defense for their so-called salvation, but in fact it is aggression and exploitation. Spivak's analysis is unique and profound, she has carefully analyzed the thoughts of the West since the Enlightenment, this grand enlightenment discourse is essentially an imperial centralist discourse that excludes non-Western civilizations. "From the deeper epistemology level, it reveals the potential colonial logic of self-evident axioms, pointing out the infiltration power of imperialism ideology as a kind of 'cultural hegemony' and discourse field".[9] ${ }^{96}$

Based on the hypocritical nature of colonial discourse, Achebe creatively used the special language and vocabulary belonging to African tribes. In this transformation of language, Africa's inexplicable words became explicable. He used English to create novels, which is a helpless choice of facts, but it is also a strategic consideration. The use of English as a language is limited (superficial colonialism can be eliminated by the colonized people, but more unconscious colonial desires cannot be eradicated), then it cannot fully convey African experiences. Certain special emotions and experiences in Africa must be meaningful and valued through the special expression of Africans themselves.

\section{ACHEBE'S CHOICE OF ENGLISH: NATIONAL LITERATURE RATHER THAN ETHNIC LITERATURE}

American philosopher Richard Rorty pointed out from a postmodern perspective that language is full of contingency, which is the result of human arbitrariness. Since language is arbitrary, there is no need for human beings to be bound by existing languages. "We should create our own new vocabulary if it is more conducive to solving our own problems".[10] ${ }^{442}$ If we understand the language from the perspective of it is always a changing state, and treat it with a postmodern deconstruction thinking, then there is really no need to be too obsessed with the anxiety of language use. Whether use African language or European language, the contingency of social development and the arbitrariness of human choices determine that the world we construct which based on language is not a constant place, any fixed thinking mode and ideology are ultimately meaningless. But the problem is that for a society that has been subjected by colonial rule and slavery for a long time, foreign language has become a living situation and integrated into people's daily life, and there is no written language in Africa's native history for reference. This dilemma has determined that the choice of foreign languages in African literary creation is a choice from no choice. Achebe and Kenya's Ngugi have a stark contrast to the question of whether African literature should use foreign language or native language. Ngugi pointed out in "Decolonization of Mind: Language Politics in African Literature" that use European language to talk about African literature is not only absurd, but also falls into the conspiracy of Western imperialists attempting to permanently enslave Africa. He expressed severe criticism to Achebe and others who used English to write African literature: "They are still accomplices of imperialism, especially Senghor and Achebe, and more prominent is Achebe..." [11] ${ }^{96}$ In Achebe's opinion, the choice between English and African is not an issue of "either this or that" but "both are fine".

Achebe chose to use English to create, not entirely because the universality of English, but depends on the history and reality of Africa. Taking Nigeria where Achebe lived as an prominent example, "As long as Nigeria wants to exist as an independent country, in the foreseeable future it has no other option expect use one foreign language which is English to unite more than 200 nationalities together". [11] ${ }^{100}$ People who speak different languages want to achieve cultural understanding, and the only way is rely on a unified language, a common and commonly used language. "Colonialism stirred up many things in Africa, but it did create a grand political entity which used to be a large number of dispersed individuals".[12] ${ }^{28}$ In Nigeria, it is English that enables this communication purpose. After the British occupation of Nigeria, the circulation of English became the primary factor in overcoming barriers to language communication. The linguistic and ethnic miscellaneousness of Nigeria, which also has no written history as in other parts of Africa, is an inevitable result of its acceptance of English. In modern history, due to a combination of factors such as the colonial invasion of the West and the inefficiency of leaders, it has caused its great decline. The long battle between the domestic tribes (Horsa in the north, Yoruba in the west, and Ibo in the east) to some extent has increased the westernization of the language when they sought after foreign aid. Therefore, mainly speaking, it was not English that chose Nigeria but Nigeria chose English.

Achebe pointed out that choosing English is not only a natural thing, but also can help Africa remove colonial rule and handle various ethnic diplomatic affairs. The use of English promotes the convenience of communication and can also be a weapon of resistance. In Africa, there are two types of people who have difficulties in language issue; one is the tactical 
players who have ulterior motives. They use language issue to cover up the "complexity of reality and our situation"; the other type writers with conscience, take Ngugi as an example, he considered language issue as a struggle against imperialism, is an extreme ideological and political tool. For the former, Achebe used "distortion of history" to describe it; for the latter, it was "a Manichaemic view of the world"2. Ngugi was trapped in a linguistic political trap which has binary opposition in essentialism. The prevalence of African English not only is because it is "conformity to actual needs", but also because its ability to advance the chaotic situation in Africa towards to the goal of unification. As the ambassador of communication and exchange, language laid the foundation for the unity and development of the nation. "Today's African countries seldom eliminate the language as the past colonial power, and this language still serves as a tool for common communication. Therefore, African writers who choose to create in English or French are not unpatriotic or the wisenheimers who use one eye to see things far away from the motherland. Language is a byproduct produced during the birth process of new countries in Africa".[11] $]^{28}$

According to Fermi Osofisan, a famous contemporary dramatist in Nigeria, the reason why Achebe became an outstanding representative of African literature to a large extent is the use of dominant colonial English. The nationstates that have been put together by the colonists actually have very different internal differences. Some of them even have no common culture. There is hostility and vendetta among them, and ethnic conflicts and contradictions are even worse because of colonists' intentional invasion. At present, Nigeria has more than 300 native languages. It is impossible to promote any native language as a unified language throughout the country. The biggest solution is to leave the conflicts open, use a language that has practical value in real life, and naturally form a lingua franca. ${ }^{3}$ This idea is consistent with Achebe's choice of language.

In Africa, the use of language also involves the definition of "African literature". For some people, the literature about Africa written in European language is not African literature, it can only be European literature. In Achebe's view, "This is too dogmatic. There is a proof that these European languages were written in today's Africa because these languages are spoken in Africa".[13] ${ }^{74}$ "The real literature is written in national languages. Ethnic literature is only spread within a certain ethnic group in a nation".[12] $]^{27}$ Therefore, English writing is national literature, and writing in languages such as Hausa, Ibo, Yoruba, etc. is ethical literature. But at the same time, he also believes that "the development of African literature requires the use of African languages. This is not one or the other, but both". [13] "The real question is not whether Africans can

Manichaeism was founded in the 3rd century by Perse's Mani, it advocated the idea of binary opposition, such as the opposition between darkness and light, the opposition between good and evil, and advocate light and goodness.

The viewpoint is from a collection of papers written by the Department of Asian and African Languages and Literatures of the School of Foreign Languages, Peking University: "The Dance of Ceremonies - From Achebe to Fugard", 2014. Among them, Femi Osofisan's paper is "Literature in Nigeria After the Achebes and Soyinkas" write in English, but whether they should write in English".[12] ${ }^{30}$ It also means that the use of English in Africa has become an inevitable phenomenon in history. Then can English become an effective tool for African writers to describe Africa? Achebe pointed out, "I think English can carry the weight of my African experience. However, it must be a new type of English. It can be used to communicate in English which from its home country, but it must be changed to accommodate the new African environment". [12 $]^{30}$

It can be seen that in the choice of language, Achebe is not an essentialist or nationalist, but he thinks from the actual utility of language and the way of communication, and regards language as an intermediary and bridge to achieve communication between Africa and Europe. However, Ngugi's consideration was not unreasonable. Languages carry cultures, If English is used without paying attention to the colonial ideology it wraps, it may inadvertently fall into the cultural envelopment of Western universalism. This is a potential cultural erosion that should arouse the vigilance of Africans. Achebe also has a profound and sober understanding of this issue. The reason why English is hated is because it carries questionable values and "racial arrogance and violence discrimination". It is precisely this kind of violence that sets the world in the flames of war. "But let us not discard the good ones while rejecting the evil ones". This kind of contradiction, which is both full of reason and full of vigilance for the use of English, appears to Achebe that there is no need to be too nervous. Because language can be changed, it is not something that is fixed.

\section{LANGUAGE HYBRID AND CROSS-CULTURAL "TRANSLATION"}

Language is a symbol of identity and it is also a powerful weapon for resistance. In the ambiguity of the colonial discourse, a "third space" was opened up for the colonized people. Language hybrid means the formation of cross-cultural "translation". Achebe achieves the purpose of resisting the Empire language and narrative through language hybrid.

\section{A. Language Hybrid and "The Third Space"}

The choice of language is related to the identity of the person. Completely copy the language of the colonists is equivalent to the direct recognition of the status quo of slavery. British writer Elleke Boehmer analyzed and presented in his hugely influential work "Colonial and Post-colonial Literature" that we should encourage a kind of diversified English, not colonial suzerainty English, which is consistent with the views of post-colonial theorist Bill Ashcoft presented in "The Empire Writes back". Achebe believes: "The cost of the world language is to yield to different kinds of use. The purpose of African writers to use English is to best express their opinions without changing the value of English as an international communication tool.]". [12 $]^{30}$ Achebe made a mixed rewriting of English and advocated "lowercase English". The so-called "lowercase English" is a linguistic and political strategy that by inserting words or phrases different from Imperial English into Imperial English, the "capital English", to reset in terms of meaning or structure so as to effectively convey the thoughts and feelings of the colonial people. The rewritten "lowercase 
English" is not only conducive to the dissemination and circulation of the general experience of the colonial people, but also conducive to the resistance of hegemonic conquer of Imperial English and the dominance and ban on the colonial people. The "lowercase English" after the adaptation of Achebe is a kind of "African-style English" that contains the African cultural personality. It is not entirely the application of English. Postcolonial writers achieved the goal of subverting colonial discourse through the rewriting of foreign languages.

Achebe believes that writing itself is a kind of translation that translates what you think and hear into a language. But some things cannot be translated from one language to another. For example, the patron saint of the Ibo people "Chi" ${ }^{4}$, it is impossible to convey its profound meaning in English. Therefore, it is necessary to retain a primitive state and use "chi" instead of the English translation so that it does not lose the uniqueness of the nation. This is actually a strategic rewrite, focusing on the characteristics and individualized voice of Africa. It conveys the voice directly from within Africa, through the further explanation of Achebe, we can understand the deep national connotation reflected by this word and its full cultural significance. Other words such as "Obi" 5 , "Osu" 6 and so on are all reflected in his novels. The rewritten language can visually convey the colonial people's life experience, thus realizing the identity positioning of the colonized person. When Achebe applied the unique vocabulary of African culture to English, a political strategy of deconstructing Empire language was presented to people, achieving the purpose of subverting and rewriting "Capital English" with "lowercase English".

Thomas Kuhn believes that there is translation incommensurability between paradigms before and after the scientific revolution in the same cultural tradition. This is in terms of historicity. we borrow this concept and believe that synchronic translations between different languages also have incommensurability. For literary creation, each country's language and culture form a "patterned resistance" in history, which formed a reception resistance for other country's language and culture. However, the different aspects of translation are only from the aspect of resistance, it does not fully prove that the two languages and the culture behind the language are completely incommunicable. In fact, human

A unique name for Africans, each one has its own patron saint, and they call it "Chi". The fate of the individual is closely linked to the patron saint.

"Obi" refers to a kind of lodge unique in Africa, where Achebe adopts direct English translation to highlight African characteristics.

"Osu" refers to the person chosen by the African tribe to devote himself to God. They used to practice living sacrifice, now because the bloody so abolish the living sacrifice, but the elected family is still considered unclean, especially women, they can't get married.

The so-called "patterned resistance" refers to the structured and patterned paradigm formed by national languages, culture, history, religion, customs, society, politics, ethics, and economy, and it has spontaneous resistance to the paradigm deposited on another national group, which ultimately highlights the uniqueness and autonomy of this nation. See Yang Naiqiao: "Comparative Literature and the Third Literary Criticism Discussing the Possibility of Comparative Literature Being Involved in the Contemporary Literature Study", "Eastern Academic Journal", No. 2, 2012, p. 4. beings share a common physiological and psychological emotional structure, which determines that our thinking patterns and thinking habits have the same similarities. For example, the attention to life, death, love, hate, the sympathy for the weak, the resistance to violent power, etc. In fact, Thomas Kuhn modified his previous views in later theories, admitting that the theory has commensurability. This is equivalent to the fact that language and language has commensurability, and there is a possibility of commensurability between culture and culture. Achebe's practice of language application further highlights that language generation is not pure, but a multi-mixed phenomenon. It is in this kind of similar and different language practice that the post-colonial writers reached the anti-political purpose of rewriting the Empire center discourse.

Since the correspondence of words is constructed historically and artificially, the mutual translation between languages must be viewed in a dialectical manner. This is why Achebe can use African-specific vocabulary to replace English. Today, when English has gained the right to speak, if you want to win the right to life and the right to speak for the creation of this nation, "the only way out is to add local things while following the West, making the 'purity' of the Western strong discourse to be impurity...."[14] $]^{22}$ In order to be able to compete with Western languages and achieve a gesture of equal dialogue and communication, we must first make most people understand African literature, and this must use generally accepted Western languages, especially English. Only in this way can African literature be read and understood by more outsiders, thereby producing greater social and humanistic values. On this basis, the elements of African native language are added, so that the language is no longer purely a monotonous voice, but a mixture of African-style English and source English. In this kind of chorus, the rebellious posture formed, the meaning of the dialogue is generated.

It is in the "hybrid" of African language and English that it has the meaning of an intercultural dialogue. In Bakhtin's view, the mixture between two languages is a hybrid. He believes that there are unconscious "organic hybrid" and "intentional hybrid" two types between languages. For any language formed in human history, it has undergone an unconscious hybrid process with other languages in history, which is called "organic hybrid". Bakhtin values more about the "intentional hybrid" of language because it is political and competitive. It is under this concept of "intentional hybrid" that laid the foundation for his dialogue theory. It places different languages in one text, allowing different sounds to filled in texts. Each character interprets others and himself from his own perspective, exposing, questioning, and interpreting each other, and ultimately an equal dialogue relationship arises. This is Bakhtin's dialogue theory that later had a huge influence. The revelation of this linguistic hybrid to the postcolonial theorist, Homi Bhabha, is that it can effectively resist the colonial discourse and thus establish the subjectivity of colonial discourse. Bhabha believes that: "If the effects of colonial power to be seen as a hybrid production, ... it made a subversion possible, ... this subversion turned the discourse conditions into a interfere reason".[15] It is precisely this 
linguistic heterogeneity that Bhabha sees as evidence of the weak resistance of colonized people. In this weak resistance space, the colonist's discourse is no longer single, and the discourse meaning of colonized people is highlighted. On one hand, the hybrid spreads and loses the meaning of the colonial discourse itself, and on the other hand it made other's language into the colonial discourse, making it from single voice to double voice, thus questioning and challenging the colonial discourse itself from within. $[16]^{51}$

This kind of hybrid brings a brand new cultural space, the "third space", which is "a space of knowledge and resistance and beyond binary opposition". Bhabha believes that "in the process of cultural translation, it will open up an 'interstitial space', an intertemporal space, which opposes returning to primitive 'essentialism' self-consciousness and also opposes letting it go into an endlessly divided subject in a 'process"'. $[17]^{204}$ This "interstitial space" is the "third space", and this cross-cultural hybrid field brought by culture cross opens up a new world for Bhabha. In this new space, Bhabha sees the possibility of colonized people's resistance. Bhabha believes that the discovery of "the third space" has made the colonized people see hope. They are no longer obsessed with the hegemony and authority of the colonial discourse. Instead, they use hybrid discourse to subvert the monolithic authority discourse and send colonized people's own voice. Although this voice is very weak, it is after all a beginning. It is the beginning of questioning the colonial discourse and opens up a whole new space of resistance. It provides a political cultural strategy for the colonizers to liberate their own ideas and culture. It is in the cultural translation space that "the old ethnic border has collapsed, the central industry has disappeared, and culture has become a translation-based, transnational meaning production process. It is in this translating, transnational gap, a brand new meaning and time appears".[18] $]^{88}$

Achebe's subversion of English hegemony, through the strategic application, language substitutions and the reversal of rules, reverses the fixed-time pattern of English expression. It showed that the Western meaning of English expression was not fixed, it is fluid, Western has Western significance, and Africa has African significance. The significance of Africa cannot be shaped by Western English, it must have its own representational model and phonation rule. This rule is to reverse empire English and achieve normal and true communication of African experience. The colonial discourse itself is not impeccable, it is based on anxiety. Colonial power is a consequence of contradictions and conflicts, colonial power is not an absolute authority, the colonized people is not completely passive, there is a vague state between them. It is precisely this kind of vague that makes the discussion between cultures and the colonial resistance possible. The colonial state was maintained and established by the colonists and the colonized people, no one can do it alone. The colonial discourse is not a monolithic whole, and its expression is full of contradictions, both positive and negative. "The colonial discourse does not merely represent others, but rather it is simultaneously designing and denying its difference, a contradictory structure made from uncoordinated logic according to fetishism. Its rule is always clear, but it has also been often slipped down, and been replaced constantly, and it has never been completed". [19] ${ }^{203-204}$ It is the contradiction and flaws that provide a space for the colonial resistance discourse, and thus laid the foundation for the possibility of cultural-cross hybrid. This state of contradiction has broken Sayed's view of colonial relations only as the boundary between colonists and colonized people. In fact, the relationship between the two is not simple binary and distinct. The original intention of the colonists was to create obedient people in the colonies, meaning to completely imitate their own words, but in fact, because of the arrogance and contradiction of the colonists themselves, they want the colonized people to be the same like themselves, but they also feared that their true imitation would threaten their status, so this contradictory attitude led to colonial people's imitation was untrue and unsuccessful in the minds of colonialists. The colonized people expressed their admiration for the Western culture that represents modern civilization, but at the same time, they have a resistance emotion because of the indifference of colonial discourse to themselves, this kind of contradictory feeling of hatred and love made them and colonial discourse have a relationship that both attracts and excludes, thus, a mixed cultural space is open, which provides a possibility for Bhabha to psychologically release the cultural inferiority of the colonists and the weak resistance of culture. In order to resist the colonial discourse, the colonized people adopted a simulation strategy. The simulated discourse is a contradictory construction, to make it effective, the simulation will produce slippage and difference. "So, simulation is a double-voiced symbol. It is a complex strategy of reform, statute, and disciplinary. When it visualizes power, it also 'appropriates' the 'others' (colonists). However, simulation is another kind of symbol, indicating inappropriate, one kind of difference or a stubborn understanding, it condenses the dominant tactical function of colonial power, strengthens supervision, and issues an internal threat to both 'standardized' knowledge and disciplinary power".[15] ${ }^{86}$ The double vocalization made the colonial discourse a mixed space of culture and discourse. "The strategic reversal of the control process... turned back by the eyes of the discriminator and toward to the eyes of power".

However, Bhabha's problem is that it is too entrenched in the theory of cultural discourse, he puts the cultural resistance on the psychological resistance, which in fact absorbs the psychological analysis result of Fanon. While Fanon rebelled against the colonialists, he also raised the issue of violent revolution that changed the reality. For this, Bhabha kept silent and expressed his misunderstanding of Fanon to some extent. As Bhabha said, whether in the colonial period or in the postcolonial period, people could not get rid of the colonial language and never learn it. This is the dilemma brought by history, and it is also the inevitable contradiction brought by differences in culture and language. However, this is precisely the advantage of the post-colonial people because they deliberately mixed the vocabulary with many local features of the local culture into the discourse, and made the Western theoretical discourse lose its pureness.

Africa's Achebe just took advantage of this position. Not only he used English to convey African experiences very well 
but also he made African literature more widely known. The more important significance is that Achebe used his overthrowing strategy of reverse writing to make the Empire language and discourse hegemony lose their central position. In a mixed language and cultural space, the qualities of all aspects have been manifested. However, just as Bhabha's theory focuses on the discourse rebellion of cultural psychology, Achebe's language rewriting could not completely repel the culture of the empire. At this point, many postcolonial theorists and scholars, such as Robert Young, Aijaz Ahmed, Arif Dirlik, Bartle Moore-Gilbert, and Boehmer, are all raised their own questions and reflections on the "Empire rewrite" strategy. In particular, Arif Dirlik believes: "Fleeing away from the scorn and stigmatization of rhetoric the grand narratives of revolution and liberation, and returning to a politics based on material, social, and existential, it seems to be imminent".[20] ] 77-78 Especially in the era of globalization, without clear understanding of reality and an objective attitude towards history, cultural resistance discourse will fall into empty talk. The Indian Marxist critic Ahmed criticized the hybrid theory: "The 'hybridity' hides the fact that the equal status of commodity culture lies only in the commodification itself, yet the historicity of all cultures is stripped from the specimen, and reduce them into interchangeable lowest common denominator but does not produce the universal equality of all cultures, only produced a grand unification culture of the late imperial market". [21] 272-273

In fact, when it is not clear that the subject of hybrid, the object of hybrid, who holds the right of hybrid discourse, etc., it may fall into the ideological trap which the imperialist planned intentionally. In the already unequal exchanges, imperialism is just happen to hold welcome attitude to hybridism, because they have mastered the discourse right of hybrid, and the interests have been tilted toward them, no matter what discourse style you take, they are manipulating the rules of the game. Therefore, before hybrid, you must first figure out who the hybrid subject is. It is either turning a blind eye to the facts, or a naive attitude that is too ignorant if you advocate hybrid rashly. Simply sticking to the hybrid nature may turn a blind eye to the power differences under the cover of ideology.

\section{B. Cross-cultural "Translation"}

The "Babel Tower" of language means the confusion between languages, and the confusion of languages can only be communicated through translation. Benjamin believes that all languages are translation of the language of God. In his view, there are three languages in the world: the language of God (meta-language), the language of human, and the language of things. Human receives the ability to name things from God, translating the language of all things into the language of human, and making the language of things from silent to vocal, from unknown to known, from imperfect to more perfect. But from the variation of God's language, language is undoubtedly lost some kind of "halos" and become untranslatable.

In the translation of language, there are indeed some untranslatable elements, but the charm of translation lies in such untranslatable translatability. With the universal stipulations between words and objects, this kind of one-to-one disciplinary translation has become a universal trend, and the resistance factor in translation which is untranslatability has gradually been neglected or even abandoned. For example, the translation of English is the case, according to Benjamin's understanding, when people all over the world use English, it is actually a translation of English. While many people are pursuing the application of standard English, and the local ethnic special emotion under this kind of universality is ignored and replaced by a homogenous British-style emotion.

Therefore, for African writers who write in English, the pursuit of standard use of English is totally unnecessary, and it will give their creations an anxiety that they cannot express local native feelings. When everyone adopts a unified standard of English, translation loses its proper meaning. In Benjamin's view, normal translation is a kind of translation that pursues differences and is a complementary relationship between languages. It is in the pursuit and communication of language repairs and differences that a true state meta-language emerges, which is Benjamin's so-called "pure language". Derrida also believes that something must be lost in translation, he sums it up as "smearing", which means that during the translation process, some invisible things have disappeared, but their traces still there. We could find something that has been dissipated or resisted from this invisible trace.

The measure taken by Achebe is to replace the words that cannot be expressed in English with the unique vocabulary of Africa, or to use the standard English that cannot fully understand this unique phenomenon belonging to Africa. The translator brings the language from one cultural space to another, and the source language gains new vitality in the target language space, but the information conveyed is not equal. "The original text survives in the translation because the act of translation activates a static, homogenous source text, which allows it to acquire otherness, so that the same culture can be sustained in other cultures, and at the same time change the historical fate of other cultures". [4] ${ }^{197}$ It is said that when Achebe switched between the two languages, it was actually two cultural traditions that were fighting each other. "Transactions between languages are always a confrontational place for national and international struggles". [22] Achebe's intentional cultural translation strategy is to make the suppressed and silent African other people start their own voices and make their voices where English can't speak or not fully sound.

If we regard English as the source language, natural African native language is the target language. From standard English creation to mixed creation with African native language, this is not only a contest between the two languages, but also a game between the two cultures. The activation and transformation of African experience in English communication is beneficial to the dissemination of valuable experience in Africa, but it also loses the true face of African experience. However, after Achebe's strategic rewriting, such as the insertion of African native vocabulary, idioms, slang, fables, etc., to compensate for the loss of this cultural translation. As a result, not only the general experience of English has gained more space to play, but more importantly, African native experience has gained an opportunity to change 
historical destiny in this language conversion and cultural interaction.

This is a win-win situation between two languages and two cultures. It is the variability and complementarity of language that provides Benjamin with a redemptive path in a broken postmodern society. His concern for the differences in translation and the interactive interpretation of language and culture are also the important significance for us to understand the strategic rewriting of Achebe.

\section{CONCLUSION}

Achebe's language hybridization strategy on the one hand subverted the "cognitive violence" of Western colonial English; on the other hand, it kept the appearance of the true voice of Africa, and truly presented the history and reality of the postcolonial African society. In the increasingly realistic dimension of intercultural literature, achebe is undoubtedly the pioneer of post-colonial culture and literature.

\section{REFERENCES}

[1] [US] Frederick Jameson. The prison of language-Marxism and Form [M]. Translated by Qian Jiaoru and Li Zixiu. Nanchang: Baihuazhou Literature and Art Publishing Company, 1995. [美] 弗雷德里克.詹 姆逊. 语言的牢笼一马克思主义与形式 [M] . 钱佼汝、李自修 译. 南昌: 百花洲文艺出版社, 1995 .

[2] Sheng Ning. Humanistic Perplexity and Reflection: Criticism of Western Postmodernism Trends [M]. Beijing: SDX Joint Publishing Company, 1997. 盛宁. 人文困惑与反思一西方后现代主义思潮批 判 [M] . 北京: 生活·读书·新知三联书店，1997。

[3] Charles C. Lemert and Garth Gillan, Michel Foucault. Social Theory and Transgression[M].New York: Columbia University Press, 1982. Charles C.Lemert and Garth Gillan, Michel Foucault. Social Theory and Transgression $[\mathrm{M}]$.

[4] Chen Yongguo. Theoretical escape [M]. Beijing: Peking University Press, 2008. 陈永国. 理论的逃逸 [M] . 北京：北京大学出版社, 2008.

[5] [FR]Frantz Fanon. Black skin, White Mask [M]. Translated by Wan Bing. Nanjing: Yilin Press, 2005. [法] 弗朗兹.法侬. 黑皮肤, 白面 具 [M]. 万冰译. 南京: 译林出版社, 2005

[6] [GR] Walter Benjamin. Literary Selection of Benjamin [M]. Edited by Chen Yongguo and Ma Hailiang. Beijing: China Social Sciences Press, 2011. [德] 瓦尔特.本雅明. 本雅明文选 [M] . 陈永国、马海良 编. 北京: 中国社会科学出版社, 2011 .

[7] [FR] Jean-Paul Sartre. Autobiography of Sartre[M]. Huang Zhongjing, Huang Wei. Tianjin: Tianjin People's Publishing Company, 2008. [法] 让-保尔.萨特. 萨特自述 [M] . 黄忠晶、黄巍. 天津：天 津人民出版社, 2008 .

[8] [IN] Gayatri C. Spivak. Rational critical of Post-colonialism - The Disappearing Present History [M]. Translated by Yan Peiwen. Nanjing: Yilin Press, 2014. [印度] 佳亚特里.斯皮瓦克. 后殖民理性批判— 一正在消失的当下的历史 [M] . 严蓓雯译. 南京：译林出版社， 2014 .

[9] Li Yingzhi. Deconstructed Cultural and Political Practice: Spivak's Postcolonial Cultural Criticism Study [M]. Shanghai: Shanghai SDX Publishing Company, 2008. 李应志. 解构的文化政治实践——斯皮 瓦克后殖民文化批评研究 [M] . 上海：上海三联书店，2008.

[10] [US] Samuel Enoch Stumpf, James Fitzgerald. The History of Western Philosophy - From Socrates to Sartre and Later (Revised 8th Edition) $[\mathrm{M}]$. Translated by Deng Xiaomang. Beijing: World Book Publishing Company, 2009. [美] 萨穆尔·伊诺克·斯通普夫、詹姆斯·菲泽. 西 方哲学史一从苏格拉底到萨特及其后（修订第 8 版) 》 [M]．邓晓芒等译。北京：世界图书出版公司，2009.
[11] Chinua Achebe. The Education of a British-Protected Child: Essays[M]. New York: Alfred A. Knopf Press, 2009.

[12] Chinua Achebe. English and the African Writer [J]. Transition, No. 18 (1965).

[13] Chinua Achebe, Kay Bonetti. An Interview with Chinua Achebe [J]. The Missouri Review, Volume 12, Number 1, 1989.

[14] Wang Ning. The study of Homi K. Bhabha's hybrid identity theory [J] Dongwu Academics. 2014(6). 王宁. 也谈“后理论时代”的理论状况 及我们的对策 $[\mathrm{J}]$. 东吴学术. 2014（6）.

[15] Homi Bhabha. The Location of Culture[M]. London:Routledge. 1994.

[16] He Yugao. The Study of Homi Baba's Hybrid Identity Theory [M] Beijing: China Social Sciences Press, 2012. 贺玉高. 霍米巴巴的杂交 性身份理论研究 [M] . 北京: 中国社会科学出版社, 2012.

[17] Homi Bhabha. "Unpacking My Library...Again", in Iain Chambers and Linda Curti, eds., The Post-colonial Question: Common Skies, Divided Horizons [M]. London: Routledge, 1966.

[18] Sheng Anfeng. The study of Homi Baba's Postcolonial theory [M] Beijing: Peking University Press, 2011. 生安锋. 霍米.巴巴的后殖民 理论研究 $[\mathrm{M}]$. 北京: 北京大学出版社, 2011 .

[19] [EN] Robert Young. White Myth - Writing History and the West [M] Translated by Zhao Xifang. Beijing. Peking University Press, 2014. [英] 罗伯特.扬. 白色神话一书写历史与西方 $[\mathrm{M}]$ ．赵稀方 译. 北京: 北京大学出版社, 2014

[20] Benita Parry. Directions and Dead Ends in Postcolonial Studies[J]. In Relocating Post-colonialism.

[21] [IN] Aijaz Ahmed. Literary Post-colonial politics. Luo Gang, Liu Xiangyu: Post-colonialist Cultural Theory [C]. Beijing: China Socia Sciences Press, 1999. [印度] 艾贾兹·阿赫默德. 文学后殖民性的 政治. 罗钢、刘象愚主编: 后殖民主义文化理论 [C]. 北京: 中 国社会科学出版社, 1999 .

[22] Liu He. Inter-lingual Writing: The Outline of the Modern Ideologica History Writing and Criticize [M]. Shanghai: Shanghai SDX Publishing Company, 1999. 刘禾. 语际书写: 现代思想史写作批判纲要 [M]. 上海: 上海三联书店，1999 